\title{
KEBIJAKAN PUBLIK DAN RITEL MODERN : STUDI KASUS PELAKSANAAN KEBIJAKAN PLASTIK BERBAYAR
}

\author{
Amrita Nugraheni Saraswaty \\ Jurusan Ekonomi Pembangunan, Fakultas Ekonomi dan Bisnis, Universitas \\ Udayana \\ Email : amritasaraswaty@gmail.com
}

\begin{abstract}
ABSTRAK
Penelitian ini bertujuan untuk mengetahui apa dampak ekonomi dari kebijakan plastik berbayar terhadap pengusaha ritel modern. Metodologi yang digunakan adalah analisis deskriptif dengan wawancara yang dilakukan pada 53 sampel ritel modern di kabupaten Badung dan Kota Denpasar, baik yang berada dalam jaringan ritel modern maupun tidak. Penelitian ini mendapatkan hasil bahwa,dari sisi ritel modern, ada kecenderungan untuk tidak membebankan tarif kantong plastik pada konsumen karena tidak ingin kehilangan konsumen. Dapat disimpulkan bahwa toko ritel modern tidak merasakan perubahan yang signifikan dari sisi ekonomi dengan kebijakan kantong plastik berbayar. Konsumen masih bersedia membayar pada harga yang ditetapkan oleh pemerintah, dan sebagian besar toko ritel modern memilih tidak menerapkan kebijakan plastik berbayar. Kedepannya,kebijakan plastik berbayar dapat dilengkapi dengan kebijakan penggunaan bahan alternatif untuk kantong belanja maupun penerapan tariff yang lebih tinggi. Sehingga jumlah kantong plastik yang digunakan dapat berkurang dan digantikan dengan bahan yang ramah lingkungan.
\end{abstract}

Kata kunci : ritel modern, kantong plastik berbayar, kebijakan publik, willingness to pay, ekonomi lingkungan

\begin{abstract}
This study aims to determine the economic impact on the modern retail businesses after the application of public policy about plastic bag fee by the government. The methodology used is descriptive with interviewing 53 samples of modern retailer in Badung and Denpasar area. This study get the result that, in terms of modern retail, there is a tendency not to impose tariffs on consumer plastic bags because they do not want to lose customers. It can be concluded that the modern retail stores do not feel any significant change of the economic policy of plastic bags fee. Consumers are still willing to pay the price set by the government, and most of the modern retail stores choose not to implement a policy of that paid plastic. Going forward, the policy paid plastic can be equipped with alternative materials usage policies for shopping bags also with a higher tariff for plastic bags. So the number of plastic bags that are used can be reduced and replaced with environmentally friendly materials.
\end{abstract}

Keywords: modern retail, plastic bags paid, public policy, willingness to pay, the economic environment 


\section{PENDAHULUAN}

Sampah dari kantong plastic telah menjadi permasalahan umum lintas benua dan negara, maupun samudera. (Haoran, 2010). Banyak negara dan kota di dunia ikut andil dalam aksi melarang penggunaan kantong plastic dalam usaha untuk mengurangi sampah dan polusi yang disebabkan oleh kantong plastik. Bagaimanapun juga, pengalaman sebelumnya telah mengajarkan bahwa kontrol terhadap sampah kantong plastik tidak akan berhasil tanpa instrument kebijakan yang tepat serta bersifat memaksa secara efektif dan persisten (Haoran, 2010).

Riset mengenai limbah plastik dari darat ke lautan menempatkan Indonesia sebagai negara terbesar kedua di dunia dalam hal penggunaan plastik dengan 3,22 juta metric ton per tahun. Hanya satu tingkat di bawah Tiongkok yang menghasilkan 8,82 juta metrik ton sampah plastik per tahun (Jambeck et al,2015). Kementerian Lingkungan Hidup dan Kehutanan serta Greeneration Indonesia melakukan penelitian yang menunjukkan ada sekitar 32 ribu toko anggota Asosiasi Pengusaha Retail Indonesia (APRINDO) yang memiliki potensi untuk mengedarkan kantong plastik sebanyak 9,6 juta atau 11,68 juta lembar perhari. Tiap tahunnya, sekitar 9,8 milyar kantong plastik terkonsumsi di Indonesia. (YLKI, 2016).

Kebiasaan menggunakan kantong plastik di seluruh dunia muncul karena plastik terbukti memberikan manfaat terkait kesehatan, keamanan, hemat energi, serta mengurangi limbah makanan melalui kemasan plastik (Andrady \& Neal,2010). Terlebih lagi karena kantong plastik menawarkan berbagai pilihan 
warna, bentuk dan motif yang beragam. Tidak jarang konsumen meminta tambahan kantong plastik untuk membawa barang belanjaan. Hal ini menggambarkan bahwa konsumen telah menjadi pengguna utama kantong plastik (Sununianti,dkk.2013). Di sisi lain, kerugian dapat muncul karena plastik merupakan bahan yang tidak dapat terurai dengan baik sehingga akan bertahan dalam jangka waktu yang lama. Plastik akan mencemari lingkungan karena terakumulasi dalam jumlah besar serta besar kemungkinan tidak dapat di daur ulang (EC DoE, 2011). Merespon pemakaian kantong plastik yang semakin meningkat dan dampak negatif yang dapat ditimbulkan, Kementrian Lingkungan Hidup dan Kehutanan (KLHK) menerapkan kebijakan publik dengan mengeluarkan surat edaran terkait percobaan kantong plastik berbayar pada toko ritel modern per tanggal 21 Februari 2016. Dalam hal peraturan pembatasan penggunaan kantong plastik, Indonesia sudah jauh tertinggal dibandingkan negara-negara lain.

Apabila ditinjau dari sisi bahan baku pembuatan plastik dengan jumlah total konsumsi plastik dalam satu tahun maka dibutuhkan 12 juta barel minyak dan 14 juta batang pohon sebagai bahan baku dasarnya. Sebagian besar kantong plastik terbuat dari sumber daya alam yang tidak dapat diperbaharui. Seperti misalnya dari penyulingan gas dan minyak bumi (ethylene). Karena berbahan dasar kimia, maka plastik akan sulit terdegradasi (non biodegradeable) dengan sempurna. Sehingga kantong plastik dapat dikategorikan sebagai produk yang tidak ramah lingkungan (Sununiati,dkk. 2013). Kondisi ini tentunya sangat memprihatinkan jika ditinjau dari sudut pelestarian lingkungan. 
Merespon pemakaian kantong plastik yang semakin meningkat dan dampak negatif yang dapat ditimbulkan, Kementrian Lingkungan Hidup dan Kehutanan (KLHK) mengeluarkan surat edaran terkait percobaan kantong plastik berbayar pada toko ritel modern per tanggal 21 Februari 2016. Dalam hal peraturan pembatasan penggunaan kantong plastik, Indonesia sudah jauh tertinggal dibandingkan negara-negara lain.

Riset dari Earth Policy Institute (2013) menyatakan bahwa Denmark memulai penerapan pajak untuk produsen kantong plastik dan kertas pada tahun 1994. Produsen selanjutnya membebankan pajak tersebut ke konsumen. Setelah penerapan pajak tersebut, terdapat penurunan penggunaan kantong plastik sampai dengan 60 persen. Sedangkan untuk wilayah Asia, Hong Kong mulai menerapkan kebijakan plastik berbayar di ritel modern pada tahun 2009 dan berhasil mengurangi penggunaan kantong plastik sebesar 75 persen pada toko-toko tersebut. Singapura mengkampanyekan "Bring Your Own Bag" atau "Bawa Kantong Anda Sendiri” sejak April 2007, dan konsumen harus mengeluarkan ekstra biaya jika ingin menggunakan kantong plastik. Hasil dari kampanye tersebut adalah di hari pertama mampu mengurangi 100.000 penggunaan kantong plastik, terjualnya 200.000 kantong non plastik yang dapat dipakai berulang kali, serta menurunnya konsumsi kantong plastik sampai dengan 60 persen. Wisconsin Department of Natural Resources mengklaim bahwa "pilihan pertama dan terbaik untuk mengurangi sampah plastik adalah untuk meminimalkan penggunaan plastik dalam kehidupan sehari-hari Anda" (Martin,2015). Mengingat infrastruktur pengelolaan sampah yang tidak efisien di Indonesia saat ini, 
termasuk Bali, dan dengan rendahnya tingkat daur ulang (Meidiana \& Gamse, 2010), maka dianggap bahwa mengurangi konsumsi plastik adalah pilihan terbaik dalam konteks yang sebenarnya bukan dengan jalan daur ulang.

Mengkonsumsi lebih sedikit kantong plastik adalah tugas yang relatif mudah bagi seseorang untuk membantu pelestarian lingkungan. Namun, tidak mudah untuk memulai perubahan perilaku seluruh masyarakat secara bersamaan. Becker et al (2014) berpendapat bahwa niat individu kurang kuat jika dibandingkan dengan kebiasaan dan peraturan kelembagaan, insentif dan dukungan memiliki kemampuan untuk mendorong perubahan perilaku dengan mengubah nilai dan tujuan dari perilaku. Larangan atau pajak atas kantong plastik merupakan contoh peraturan yang bisa digunakan.

Untuk melihat sejauh mana dampak kebijakan plastik berbayar yang sudah dikeluarkan oleh KLHK maka dalam penelitian ini difokuskan pada dampak yang ditimbulkan oleh kebijakan plastik berbayar terhadap pengusaha ritel modern dan juga terhadap lingkungan. Dampak ekonomi terhadap pengusaha ritel modern ditinjau dari sisi kerugian atau keuntungan yang dialami setelah diterapkannya kebijakan plastik berbayar.

\section{KAJIAN PUSTAKA}

\section{Landasan Teori}

\section{Kebijakan Publik}

Pengertian dan substansi tentang kebijakan publik secara langsung ataupun tidak langsung telah dikenal luas di masyarakat, seiring dengan berbagai fenomena dan 
kegiatan yang terjadi di dalam pemerintahan. Terdapat banyak pendapat yang dikemukakan oleh para ahli dengan definisi yang beragam. Kebijakan publik menurut Dye didefinisikan sebagai "Whatever governments chooses to do or not to do". Kebijakan publik adalah apa yang pemerintah pilih untuk melakukan atau tidak melakukan sesuatu (Dye,1987).

Senada dengan hal diatas Dye dalam Widodo (2008) mengemukakan bahwa dalam sistem kebijakan terdapat tiga elemen yaitu (a) stakeholders kebijakan, (b) pelaku kebijakan (policy contents), dan (c) lingkungan kebijakan (policy environment). Berdasarkan teori tersebut dapat disimpulkan bahwasannya suatu kebijakan dibuat oleh pemerintah untuk mencapai tujuan tertentu yang didalamnya terdapat pelaku pelaku yang terlibat dalam mengatasi masalah yang timbul dari lingkungannya.

Kebijakan publik tidak boleh bertentangan dengan nilai nilai dan praktikpraktik sosial yang ada dalam masyarakat, agar tidak terjadi penolakan ataupun resistensi pada saat diimplementasikan. Thoha (1992) mengidentifikasi dua aspek yang terkandung dalam kebijakan publik. Pertama, lahirnya kebijakan publik merupakan bagian dari dinamika sosial yang berarti bahwa proses kebijakan tidak berada dalam ruang hampa dan berdiri sendiri. Sebagai produk dan aktivitas pemerintahan, kebijakan terkait dengan perubahan masyarakat. Dampaknya adalah meningkatnya kebutuhan maupun permasalahan yang dihadapi oleh masyarakat dan dalam dinamikanya mengerucut menjadi isu publik sehingga mendorong lahirnya suatu produk kebijakan. Kedua, kompleksitas kebutuhan 
publik dan permasalahan yang menyertainya menjadi titik total bagi ditetapkannya kebijakan untuk mengatasi konflik kepentingan serta memberikan insentif kepada berbagai kelompok DPRD maupun kelompokkelompok kepentingan yang berasal dari sektor swasta serta lembaga swadaya masyarakat (LSM). Tiap-tiap kelompok kepentingan ini memiliki hubungan atau berinteraksi dengan aktor/elit kebijakan dengan tujuan untuk mempengaruhi pilihan-pilihan kebijakan yang akan ditetapkan.

Dari sejumlah definisi yang telah diuraikan diatas, dapat disimpulkan bahwasannya kebijakan publik merupakan serangkaian kegiatan atau proses dalam mengatasi masalah publik yang didalamnya mengandung konsep atau nilai nilai yang selaras dengan konsep dan nilai yang dianut oleh masyarakat. Kebijakan publik disusun melalui tahapan-tahapan tertentu, dimana terdapat seorang atau sekumpulan aktor di setiap tahapan-tahapan penyusunan kebijakan publik tersebut. Menurut Dunn (2003) dalam tahapan-tahapan kebijakan publik terdiri dari :

1. Tahap penyusunan agenda. Para pejabat yang dipilih dan diangkat menempatkan masalah apada agenda publik. Sebelumnya masalahmasalah ini berkompetisi terlebih dahulu untuk dapat masuk ke dalam agenda kebijakan. Pada, akhirnya beberapa masalah masuk ke agenda kebijakan para perumus kebijakan.

2. Tahap formulasi kebijakan. Masalah yang telah masuk ke agenda kebijakan kemudian dibahas oleh para pembuat kebijakan. Masalah- 
masalah tadi didefinisikan untuk kemudian dicari pemecahan masalah terbaik. Pemecahan masalah tersebut berasal dari berbagai alternatif yang ada. Pada tahap ini masing-masing alternatif bersaing untuk dapat dipilih sebagai kebijakan yang diambil untuk memecahkan masalah.

3. Tahap adopsi kebijakan. Dari beberapa alternatif kebijakan yang ditawarkan oleh para perumus kebijakan, pada akhirnya salah satu alternatif kebijakan tersebut diadopsi dengan dukungan dari mayoritas legislatif, konsensus antara direktur lembaga atau keputusan peradilan.

4. Tahap implementasi kebijakan. Kebijakan yang telah diambil dilaksanakan oleh unit-unit administrasi yang memobilisasikan sumberdaya finansial dan manusia.

5. Tahap penilaian kebijakan. Pada tahap ini kebijakan yang telah dijalankan akan dinilai atau dievaluasi untuk melihat sejauh mana kebijakan yang dibuat. Ditentukan ukuran-ukuran atau kriteria-kriteria yang menjadi dasar untuk menilai apakah kebijakan publik telah meraih dampak yang diinginkan.

Menurut Dunn tahapan-tahapan kebijakan publik tersebut dapat digambarkan sebagai berikut : 


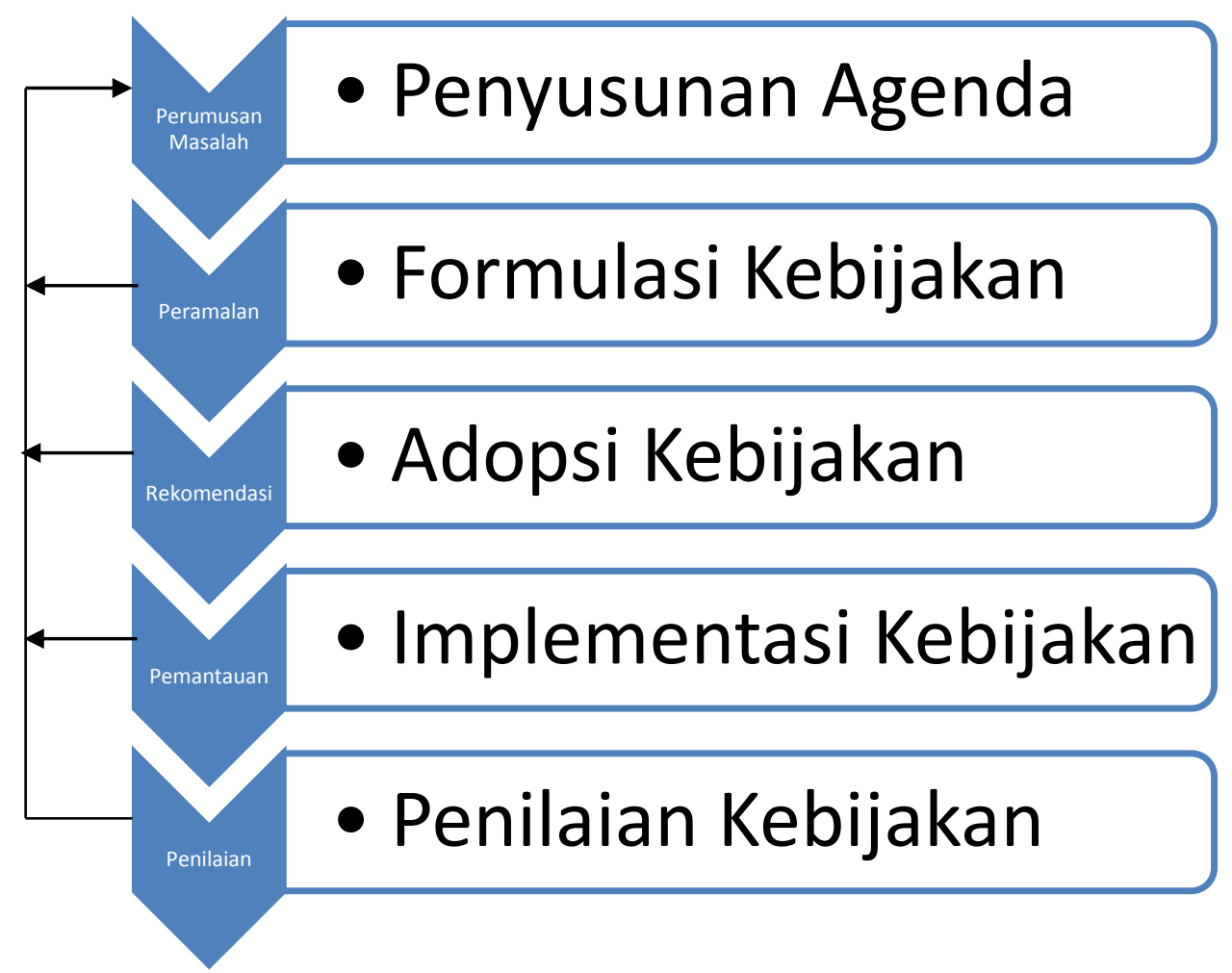

Gambar 1. Tahapan-Tahapan Kebijakan Publik

Sumber : William N. Dunn (2003)

Berdasarkan gambar diatas dapat dijelaskan bahwa analisis kebijakan publik adalah serangkaian aktivitas intelektual yang dilakukan dalam proses kegiatan yang bersifat politis. Aktivitas politis tersebut nampak dalam serangkaian kegiatan yang mencakup penyusunan agenda, formulasi kebijakan, adopsi kebijakan, implementasi kebijakan, dan penilai kebijakan. Sedangkan aktivitas perumusan masalah, peramalan (forecasting), rekomendasi kebijakan, monitoring, dan evaluasi kebijakan adalah aktivitas yang lebih bersifat intelektual.

Salah satu tahapan penting dalam proses kebijakan publik adalah tahap implementasi. Implementasi kebijakan adalah tahap lanjutan setelah kebijakan 
dirumuskan secara jelas dan suatu cara agar sebuah kebijakan dapat mencapai tujuan yang diharapkan. Widodo menjelaskan Implementasi berarti "Menyediakan sarana untuk melaksanakan suatu kebijakan dan dapat menimbulkan dampak atau akibat terhadap sesuatu tertentu".

Implementasi merupakan proses yang kompleks yang melibatkan berbagai aktor serta menggunakan berbagai sumber daya dalam pelaksanaanya dan dilaksanakan dalam kurun waktu tertentu, selain itu implementasi merupakan tahapan yang krusial dan menjadi bagian yang tidak dapat dipisahkan dari keseluruhan proses kebijakan. Bagaimanapun baiknya suatu kebijakan jika tidak diimplementasikan tidak akan menimbulkan dampak atau tujuan yang diinginkan.

Seperti yang dikemukakan oleh Hoogerwerf (Efriandi,2010) yang menjelaskan "Agar suatu kebijakan dapat memberikan hasil yang diharapkan, maka kebijakan itu harus dilaksanakan. Pelaksanaan kebijakan dapat didefinisikan sebagai pengggunaan sarana-sarana yang dipilih untuk mencapai tujuan-tujuan yang dipilih dan ingin direalisasikan".

Dalam implementasinya sendiri tidak terlepas dari berbagai kendala yang timbul akibat proses yang rumit dan kompleks, kendala tersebut menjadi penghambat dalam keberhasilan suatu implementasi bahkan dapat menyebabkan gagalnya implementasi tersebut. Karakteristik masalah merupakan salah satu dari tiga kelompok variabel yang mempernaruhi keberhasilan implementasi seperti yang dikemukakan oleh Mazamanian dan Sabatier dalam Efriandi (2010) yang mengidentifikasi Karakterisitik masalah yang terdiri atas : 
1. Kesulitan Teknis. Tingkat kesulitan teknis dari masalah yang bersangkutan, sifat dari suatu msalah itu sendiri akan mempengaruhi mudah tidaknya suatu program diimplementasikan.

2. Keragaman perilaku kelompok sasaran. Hal ini berarti bahwa suatu program akan relatif mudah diimplementasikan apabila kelompok sasarannya homogen. Sebaliknya apabila kelompok sasarannya heterogen, maka implementasi program akan relatif lebih sulit.

3. Proporsi kelompok sasaran terhadap total populasi. Sebuah program relatif akan sulit diimplementasikan apabila sasaranya mencakup semua populasi. Sebaliknya sebuah program relatif mudah diimplementasikan apabila jumlah kelompok sasarannya tidak terlalu besar.

4. Cakupan perubahan perilaku yang diharapkan. Sebuah program bertujuan memberikan pengetahuan atau bersifat kognitif akan relatif lebih mudah diimplementasikan daripada program yang bertujuan untuk mengubah sikap dan perilaku masyarakat.

Sementara itu Wahab (1997) menjelaskan bahwa suatu kebijakan gagal diimplementasikan karena disebabkan oleh faktor-faktor berikut :

1. Pihak-pihak yang terlibat dalam pelaksanaan tidak mau bekerja sama dalam kebijakan tersebut;

2. Pihak-pihak yang terlibat tersebut telah bekerja secara tidak efisien atau setengah hati; 
3. Pihak-pihak yang terlibat tidak menguasai permasalahan yang dihadapi;

4. Kemungkinan permasalahan yang dihadapi di luar jangkauan kekuasaan pihak-pihak yang terlibat dalam implementasi tersebut.

Dari berbagai hal diatas, dapat diketahui banyak kendala yang dapat menghambat keberhasilan dari pelaksanaan atau kebijakan, sehingga kebijakan yang dibuat sebelum diputuskan dan dilaksanakan harus direncanakan dengan matang sehingga peramalan yang dibuat mampu memprediksi kendala ataupun masalah yang mungkin timbul.

Sebuah implementasi agar efektif memerlukan berbagai ketepatan, Nugroho (2009) merinci prinsip ketepatan yang perlu dipenuhi dalam hak keefektifan kebijakan antara lain :

1. Ketepatan kebijakan. apakah kebijakannya sendiri sudah tepat. Ketepatan kebijakan ini dinilai dari sejauh mana kebijakan yang ada telah bermuatan hal-hal yang memang memecahkan masalah yang hendak dipecahkan.

2. Ketepatan pelaksanaan. Ketepatan dalam hal pelaksana atau aktor dari implementasi kebijakan yang akan dilaksanakan. Ada tiga lembaga yang dapat menjadi pelaksana, yaitu pemerintah, kerjasama antara pemerintah dan masyarakat/swasta, dan implementasi kebijakan yang diswastakan.

3. Ketepatan target. Ketepatan target berkaitan dengan tiga hal yaitu pertama, apakah target yang diintervensi sesuai dengan yang direncanakan, 
tidak tumpang tindih dengan intervensi lain, dan tidak bertentangan dengan intervensi kebijakan lain. Kedua kesiapan kondisi target untuk diintervensi, ketiga apakah intervensi implementasi kebijakan bersifat baru atau memperbarui implementasi kebijakan sebelumnya.

4. Ketepatan Lingkungan. Terdiri atas dua lingkungan yaitu lingkungan kebijakan yaitu interaksi diantara lembaga perumus kebijakan dan pelaksana kebijakan dengan lembaga lain yang terkait. Serta lingkungan eksternal kebijakan yang terdiri atas persepsi publik atas kebijakan, interpretasi lembaga strategis dalam masyarakat, dan individu-individu tertentu yang memiliki peran penting dalam menginterpretasikan kebijakan dan implementasi kebijakan

Evaluasi merupakan salah satu tahapan penting dalam proses kebijakan publik, namun seringkali tahapan ini diabaikan dan hanya berakhir pada tahap implementasi. Evaluasi adalah kegiatan untuk menilai tingkat kinerja suatu kebijakan (Efriandi, 2010). Evaluasi kebijakan digunakan untuk mengukur keberhasilan dan kegagalan pelaksanaan suatu kebijakan publik. Menurut Muhadjir dalam Widodo (2008) mengemukakan "Evaluasi kebijakan publik merupakan suatu proses untuk menilai seberapa jauh suatu kebijakan publik dapat "membuahkan hasil", yaitu dengan membandingkan antara hasil yang diperoleh dengan tujuan dan/atau target kebijakan publik yang ditentukan". Hal ini berarti bahwa proses evaluasi tidah hanya dapat dilakukan pada tahapan akhir saja, melainkan keseluruhan dari proses kebijakan dapat dievaluasi. 
Sebagai salah satu tahapan dalam proses kebijakan, evaluasi memiliki fungsi dan tujuan. Menurut Wibawa dalam Nugroho (2009), evaluasi kebijakan publik memilik empat fungsi, yaitu:

a. Eksplanasi. Melalui evaluasi dapat dipotret realitas pelaksanaan program dan dapat dibuat suatu generalisasi tentang pola-pola hungungan antar berbagai dimensi realitas yang diamatinya. Dari evaluasi ini evaluator dapat mengidentifikasi masalah ,kondisi, dan aktor yang mendukung keberhasilan atau kegagalan kebijakan.

b. Kepatuhan. Melalui evaluasi dapat diketahui apakah tindakan yang dilakukan oleh para pelaku, baik birokrasi maupun pelaku lainnya, sesuai dengan standar dan prosedur yang ditetapkan oleh kebijakan.

c. Audit. Melalui evaluasi dapat diketahui, apakah output benar-benar sampai ke tangan kelompok sasaran kebijakan, atau justru ada kebocoran atau penyimpangan.

d. Akunting. Dengan evaluasi dapat diketahui apa akibat sosial ekonomi dari kebijakan tersebut.

Evaluasi kebijakan publik memiliki tipe dan pendekatan yang beragam dan berbeda, tergantung dari pada tujuan ataupun sudut pandang dari para evaluator yang akan melakukan evaluasi. Dunn (2003) membagi pendekatan evaluasi menjadi tiga bagian antara lain : 
a. Evaluasi Semu. Evaluasi semu (Pseudo Evaluation) adalah pendekatan yang menggunakan metode-metode deskriptif untuk menghasilkan informasi yang valid dan dapat dipercaya mengenai hasil kebijakan, tanpa berusaha untuk menanyakan tentang manfaat atau nilai dari hasil-hasil tersebut terhadap individu. Asumsi utama dari evaluasi semu adalah bahwa ukuran tentang manfaat atau nilai merupakan sesuatu yang dapat terbukti sendiri (self evident) atau tidak kontroversial.

b. Evaluasi Formal. Evaluasi formal merupakan pendekatan yang menggunakan metode deskriptif untuk menghasilkan informasi yang valid dan cepat dipercaya mengenai hasil-hasil kebijakan tetapi mengevaluasi hal tersebut atas dasar tujuan program kebijakan yang telah dimumkan secara formal oleh pembuat kebijakan dan administrator program. Asumsi utama dari evaluasi formal adalah bahwa tujuandan target diumukan secara formal adalah merupakan ukuran yang tepat untuk manfaat atau nilai kebijakan program.

c. Evaluasi Keputusan Teoritis. Evaluasi keputusan teoritis adalah pendekatan yang menggunakan metode-metode deskriptif untuk menghasilkan informasi yang dapat dipertanggungjawabkan dan valid mengenai hasil-hasil kebijakan yang secara eksplisit dinilai oleh berbagai macam pelaku kebijakan. Asumsi dari evaluasi teoritis keputusan adalah bahwa tujuan dan sasaran dari perilaku kebijakan baik yang dinyatakan 
secara formal maupun secara tersembunyi merupakan ukuran yang layak terhadap manfaat atau nilai kebijakan dan program.

Evaluasi kebijakan publik, dalam tahapan pelaksanaannya menggunakan pengembangan beberapa indikator untuk menghindari timbulnya bias serta sebagai pedoman ataupun arahan bagi evaluator. Kriteria-kriteria yang ditetapkan menjadi tolak ukur dalam menentukan berhasil atau tidaknya suatu kebijakan publik. Nugroho (2009) menjelaskan bahwa evaluasi memberi informasi yang valid dan dapat dipercaya mengenai kinerja kebijakan, yaitu seberapa jauh kebutuhan, nilai, dan kesempatan telah dapat dicapai melalui tindakan publik. William N. Dunn (2003) mengemukakan beberapa kriteria rekomendasi kebijakan yang sama dengan kriteria evaluasi kebijakan, kriteria rekomendasi kebijakan terdiri atas :

a. Efektifitas (effectiveness). Berkenaan dengan apakah suatu alternatif mencapai hasil (akibat) yang diharapkan, atau mencapai tujuan dari diadakannya tindakan. Efektifitas, yang secara dekat berhubungan dengan rasionalitas teknis, selalu diukur dari unit produk atau layanan atau nilai moneternya.

b. Efisiensi (efficiency). Berkenaan dengan jumlah usaha yang diperlukan untuk menghasilkan tingkat efektifitas tertentu. Efisiensi yang merupakan sinonim dari rasionalitas ekonomi adalah merupakan hubungan antara efektifitas dan usaha, yang terakhir umumnya diukur dari ongkos moneter. 
c. Kecukupan (adequacy). Berkenaan dengan seberapa jauh suatu tingkat efektifitas memuaskan kebutuhan, nilai, atau kesempatan menumbuhkan adanya masalah. Kriteria kecukupan menekankan pada kuatnya hubungan antara alternatif kebijakan dan hasil yang diharapkan.

d. Perataan (equity). Erat berhubungan dengan rasionalitas legal dan sosial dan menunjuk pada distribusi akibat dan usaha antara kelompok-kelompok yang berbeda dalam masyarakat. Kebijakan yang berorientasi pada perataan adalah kebijakan yang akibatnya (misalnya, unit pelayanan atau manfaat moneter) atau usaha (misalnya biaya moneter) secara adil didistribusikan. Kebijakan yang dirancang untuk mendistribusikan pendapatan, kesempatan pendidikan, atau pelayanan pendidikan kadangkadang didistribusikan atas dasar kriteria kesamaan. Kriteria kesamaan erat berhubungan dengan konsepsi yang saling bersaing, yaitu keadilan atau kewajaran dan terhadap konflik etis sekitar dasar yang memadai untuk mendistribusikan risoris masyarakat.

e. Responsivitas (responsiveness) berkenaan dengan seberapa jauh suatu kebijakan dapat memuaskan kebutuhan, preferensi, atau nilai kelompokkelompok masyarakat tertentu. kriteria responsivitas adalah penting karena analisis yang dapat memuaskan semua kriteria lainnya - efektifitas, efisiensi, kecukupan, kesamaan - masih gagal jika belum menanggapi kebutuhan aktual dari kelompok yang semestinya diuntungkan dari adanya suatu kebijakan. 
f. Ketepatan (appropriateness). Kriteria ketepatan secara dekat berhubungan dengan rasionalitas, substantif, karena pertanyaan tentang ketepatan kebijakan tidak berkenaan dengan satuan kriteria individu tetapi dua atau lebih kriteria secara bersama-sama. Ketepatan merujuk pada nilai atau harga dari tujuan program dan kepada kuatnya asumsi yang melandasi tujuan-tujuan tersebut.

Sejalan dengan kriteria rekomendasi kebijakan tersebut, Dunn mengemukakan kriteria evaluasi kebijakan antara lain :

Tabel 1. Kriteria Evaluasi Kebijakan

\begin{tabular}{|l|l|}
\hline \multicolumn{1}{|c|}{ Tipe Kriteria } & \multicolumn{1}{c|}{ Pertanyaan } \\
\hline Efektifitas & Apakah hasil yang diinginkan telah dicapai? \\
\hline Efisiensi & $\begin{array}{l}\text { Seberapa banyak usaha yang diperluka untuk mencapai } \\
\text { hasil yang diinginkan? }\end{array}$ \\
\hline Kecukupan & $\begin{array}{l}\text { Seberapa jauh pencapaian hasil yang diinginkan } \\
\text { memecahkan masalah? }\end{array}$ \\
\hline Perataan & $\begin{array}{l}\text { Apakah biaya dan manfaat didistribusikan dengan merata } \\
\text { kepada kelompok-kelompok yang berbeda? }\end{array}$ \\
\hline Responsivitas & $\begin{array}{l}\text { Apakah hasil kebijakan memuaskan kebutuhan, preferensi } \\
\text { atau nilai kelompok-kelompok tertentu? }\end{array}$ \\
\hline Ketepatan & $\begin{array}{l}\text { Apakah hasil (tujuan) yang diinginkan benar-benar } \\
\text { berguna atau bernilai? }\end{array}$ \\
\hline
\end{tabular}

Sumber : William N. Dunn (2003)

\section{Ritel Modern}

Ritel adalah suatu penjualan dari jumlah kecil komoditas kepada konsumen. Ritel berasal dari Bahasa Perancis diambil dari kata retailer yang berarti "memotong menjadi kecil-kecil" (Reardon and Hopkins,2006). Sedangkan menurut Kotler (1995), ritel atau penjualan eceran meliputi semua kegiatan yang 
melibatkan penjualan barang atau jasa secara langsung pada konsumen akhir untuk penggunaan pribadi dan bukan bisnis.

Izin operasi supermarket dikeluarkan oleh Departemen Perindustrian dan Perdagangan (Deperindag). Pemda umumnya tidak berwenang untuk menolak izin yang dikeluarkan Pemerintah Pusat, meskipun beberapa Pemda mensyaratkan agar supermarket memiliki Izin Usaha Pasar Modern (IUPM), yang dikeluarkan oleh Deperindag dan Izin Prinsip Pembangunan Pasar Modern (IP3M), yang dikelaurkan oleh Dinas Perdagangan dan Perindustrian Kota. Selain izin yang dikeluarkan secara terpusat, supermarket biasanya harus mendapatkan izin lokal lain yang diperlukan oleh usaha pribadi, seperti misalnya Izin Mendirikan Bangunan (IMB) maupun Izin Gangguan (HO) (Safitri,2010).

\section{Penelitian Sebelumnya}

Haoran (2010) melakukan penelitian yang berjudul The Effects of an Environmental Policy on Consumers : Lesson from the Chinese Plastic Bag Regulation. Haoran menyimpulkan bahwa, dari pengalaman pengelolaan sampah kantong plastic di Negara China yang mengeluarkan kebijakan serentak pengenaan tariff kantong plastik per 1 Juni 2008, terdapat pengurangan 49 persen pada penggunaan penggunaan kantong plastic. Disamping dengan adanya penerapan regulasi, perilaku konsumen terhadap regulasi tersebut dan beberapa karakteristik sosio ekonomi dari konsumen juga turut berpengaruh terhadap konsumsi kantong plastik. Bagaimanapun juga, efek dari regulasi berbeda cukup besar diantara kelompok konsumen, kawasan dan kesempatan belanja. 
Gusmayanti,dkk (2011) melakukan penelitian yang berjudul Pengenaan Harga Kantong Plastik Sebagai Upaya Mereduksi Penggunaan Kantong Plastik di Depok, Jawa Barat. Dalam penelitian tersebut disimpulkan bahwa terdapat hubungan antara kesediaan konsumen membayar setiap kantong plastik pada tingkat harga tertentu dan jenis kelamin, jenis pekerjaan, usia, dan tingkat penghasilan. Sebanyak 97 persen responden bersedia untuk mengurangi jumlah kantong kresek yang diterima dari penjual. Kesediaan untuk membayar pada tingkat harga tertentu didominasi oleh perempuan. Sebesar 75,7 persen perempuan bersedia membayar seharga Rp.50 dan merupakan 25 persen dari jumlah seluruh responden perempuan. Total keseluruhan responden yang bersedia membayar (pada tingkat harga yang ditentukan) berjumlah 114 orang. Sebanyak 31 orang atau 27,2 persen berasal dari kelompok usia 20-24 tahun dimana jumlah pada kelompok usia ini adalah 42 dari 171 responden. Berdasarkan jenis pekerjaan, proporsi terbesar yang bersedia membayar adalah pegawai swasta (32 orang) dan mahasiswa (30 orang). Sedangkan berdasarkan tingkat penghasilan per bulan, proporsi terbesar adalah yang berpenghasilan $\mathrm{Rp}$ 2.500.001-Rp 3.500.000 sebanyak 21 orang atau 18,4 persen. Namun, pada tingkat harga 500/buah, persentase yang tidak bersedia membayar meningkat hingga mencapai 44.1 persen dan pada tingkat harga Rp 1000/buah mencapai 52 persen.

Penelitian tentang penggunaan kantong plastik di Bali dilakukan oleh Javier Lopez-Murcia Martin (2015) dengan judul Social Perceptions of SingleUse Plastic Consumption of the Balinese Population. Penelitian terebut berfokus pada tahap konsumsi. Secara lebih spesifik, tujuan dari penelitian yang dilakukan 
Martin adalah mencari informasi mengenai perilaku orang Bali dalam mengkonsumsi botol dan kantong plastik sekali pakai dan kesadaran mereka akan dampak lingkungan yang disebabkan dari konsumsi botol dan kantong plastik sekali pakai. Hasil penelitian yang didapatkan adalah Pertama, diperlukan usaha lebih terkait penyediaan kantong alternatif selain kantong plastik, misalnya dengan insentif ekonomi dari pemerintah kepada supermarket yang menyediakan kantong alternatif. Dan yang Kedua, fakta bahwa orang Bali makin sadar akan masalah-masalah lingkungan berdasarkan pengalaman pribadi dapat menunjukkan bahwa mereka mendapat pengaruh langsung atau sesuatu yang sering mereka saksikan. Hal ini menyiratkan bahwa diperlukan pendidikan sejak dini pada komunitas di Bali agar menerapkan kebiasaan yang lebih ramah lingkungan (sustainable practices).

Saraswaty (2017) dalam penelitiannya yang berjudul Why They Still Want To Use It? : Plastic Bag Policy Application on Modern Retailers and Consumers mennyimpulkan bahwa baik konsumen maupun toko ritel modern tidak merasakan adanya perubahan signifikan dari kebijakan ekonomi kantong plastik. Konsumen masih bersedia membayar harga yang ditetapkan oleh pemerintah, dan sebagian besar toko ritel modern memilih untuk tidak menerapkan kebijakan plastik berbayar. Sehingga kebijakan plastik berbayar yang dikeluarkan oleh pemerintah Indonesia melalui Kementerian Lingkungan Hidup dan Kehutanan pada periode 2016 menjadi kurang efektif dan tidak berlanjut. Untuk pertimbangan berikutnya, kebijakan kantong plastik bisa dilengkapi dengan penggunaan bahan alternatif untuk tas belanja dan juga cara alternatif untuk 
mengurangi kantong plastik dengan memberikan diskon khusus kepada konsumen jika membawa tas sendiri maupun dengan menaikkan tarif kantong plastik yang bertujuan mencegah konsumen menggunakan kantong plastik. Sehingga jumlah kantong plastik yang digunakan bisa dikurangi dan diganti dengan bahan ramah lingkungan.

Berdasarkan latar belakang masalah dan perumusan masalah yang ada, maka yang menjadi tujuan penelitian ini adalah : Menganalisis dampak ekonomi dari kebijakan plastik berbayar terhadap usaha ritel modern di wilayah Denpasar dan Badung

\section{METODE PENELITIAN}

Lokasi penelitian ditentukan secara sengaja (purposive) yaitu di Kota Denpasar dan Kabupaten Badung, Provinsi Bali. Kedua lokasi sengaja dipilih karena memiliki jumlah ritel modern paling banyak jika dibandingkan dengan kabupaten lain di Provinsi Bali, serta berpenduduk padat dan heterogen. Sumber data yang digunakan dalam penelitian ini adalah data primer dan data sekunder. Data primer diperoleh dengan cara menyebarkan kuesioner secara langsung kepada sampel toko ritel modern di Kota Denpasar dan Kabupaten Badung. Survei dilakukan pada responden tersampling dengan melakukan wawancara langsung, dengan dipandu instrumen penelitian berupa daftar pertanyaan atau kuesioner. Dengan segala keterbatasan sumber daya waktu, tenaga, dan biaya yang ada, maka penelitian ini diupayakan dapat memenuhi kaidah dan prosedur pelaksanaan survei secara optimal. Data lain yang dipakai untuk melengkapi 
analisis dalam penelitian ini adalah berbagai data yang diperoleh dari data sekunder. Data sekunder ini adalah data dari berbagai arsip yang dapat diperoleh dari dinas terkait yang memiliki kewenangan untuk regulasi ritel modern di Kota Denpasar dan Kabupaten Badung. Dengan pertimbangan akademik, populasi dapat diwakili oleh sebagian anggotanya yang disebut dengan sampel. Strategi pengambilan sampel tergantung pada kondisi, misalnya berapa banyak variabel yang digunakan dalam penelitian, berapa banyak karakteristik pelanggan, dan distribusi geografis populasi.

Ferdinand (2002) menyatakan bahwa ukuran sampel yang harus dipenuhi adalah minimum berjumlah 100 sampel dan selanjutnya menggunakan perbandingan 5 observasi untuk setiap estimated parameter. Karena itu bila kita mengembangkan model dengan 20 parameter maka minimum sampel yang harus digunakan adalah sebanyak 100 sampel. Dengan mempertimbangkan kapasitas sumberdaya yang dimiliki oleh peneliti, maka ukuran sampel pada umumnya yang digunakan adalah antara 30 sampai dengan 500 (Sekaran,1992). Berdasarkan targeted population di atas, selanjutnya ditentukan besarnya ukuran sampel (sample size). Teknik pengambilan sampel yang diterapkan adalah menggunakan perpaduan antara area sampling dan proportionate random sampling. Penggunaan area sampling dimaksudkan agar sebaran responden yang tersampling dapat merata mewakili lingkup wilayah penelitian. Definisi luas area atau wilayah dalam penelitian ini adalah wilayah kabupaten/kota. Adapun untuk sampel toko ritel modern, dengan mempertimbangkan keterbatasan waktu dan juga biaya maka 
sampel yang digunakan adalah 53 ritel modern di kawasan Kota Denpasar dan Kabupaten Badung.

Analisis yang digunakan dalam penelitian ini berdasarkan tujuan penelitian adalah analisis deskriptif untuk responden toko ritel modern

\section{HASIL PENELITIAN DAN PEMBAHASAN}

\section{Hasil}

Dalam penelitian ini yang dijadikan responden adalah pemilik atau karyawan di toko modern di Kota Denpasar dan Kabupaten Badung. Jumlah kuesioner yang dipergunakan untuk wawancara sebanyak 53 kuesioner untuk ritel modern. Responden pemilik atau karyawan di toko modern di Kota Denpasar dan Kabupaten Badung berjumlah 53 orang. 33 responden $(62,26 \%)$ berasal dari toko modern tanpa jaringan serta 20 responden $(37,74 \%)$ berasal dari toko modern yang memiliki jaringan (Alfamart, Indomaret, Circle K dan Mini Mart). Dari 53 responden, hanya 4 responden $(7,55 \%)$ yang menerapkan kebijakan plastik berbayar pada toko mereka, sedangkan 49 responden $(92,45 \%)$ tidak menerapkan kebijakan kantong plastik berbayar.

\section{Pembahasan}

\section{Tabulasi Silang Dampak Kebijakan dan Jenis Toko}

Hasil tabulasi silang antara dampak kebijakan plastik berbayar dan jenis toko modern menunjukkan bahwa dari 33 toko modern yang tidak termasuk toko 
berjaringan, 18 responden menyatakan jumlah konsumen yang berbelanja di toko mereka tidak mengalami perubahan setelah diterapkan kebijakan plastik berbayar pada periode April-Oktober 2016. Dalam artian, walaupun ada kebijakan plastik berbayar konsumen pada toko ritel modern tetap jumlahnya. 7 responden menyatakan bahwa responden tidak keberatan untuk membayar kantong plastik, 3 responden toko modern menyatakan konsumen membawa kantong belanja sendiri, 4 responden menyatakan sedikit merugi karena konsumen berkurang, sedangkan 1 responden menyatakan mendapatkan keuntungan setelah ada kebijakan plastik berbayar.

Dari sisi toko modern yang memiliki jaringan, dari total 20 responden, 7 responden menyatakan jumlah konsumen sama saja, 5 responden menyatakan konsumen tidak keberatan untuk membayar kantong plastik, 7 responden menyatakan konsumen membawa kantong belanja sendiri, 1 responden menyatakan sedikit mengalami kerugian. Tidak seperti toko modern tanpa jaringan, pada toko modern dengan jaringan, tidak ada responden yang menyatakan mendapatkan keuntungan dari diterapkannya kebijakan plastic berbayar.

\section{Tabulasi Silang Dampak Kebijakan dan Lokasi}

Tabulasi silang antara dampak kebijakan plastic berbayar dengan lokasi toko ritel modern menunjukkan hasil bahwa dari total 23 responden yang berlokasi di Kota Denpasar, 10 responden menyatakan tidak ada perubahan berarti dari jumlah konsumen yang berbelanja di toko mereka, 5 responden menyatakan 
konsumen bersedia membayar kantong plastic belanja, 4 responden menyatakan konsumen membawa sendiri kantong belanja sehingga tidak memerlukan kantong plastik dari toko ritel modern, 4 responden menyatakan merugi, serta tidak ada responden yang menyatakan mendapat keuntungan dari kebijakan plastic berbayar. Sedangkan dari 30 toko ritel modern yang berlokasi di Kabupaten Badung, 15 responden menyatakan bila tidak ada perubahan signifikan dari jumlah konsumen yang berbelanja di toko mereka setelah ada kebijakan plastik berbayar, 7 responden menyatakan konsumen bersedia membayar kantong plastic, 6 responden menyatakan konsumen membawa sendiri kantong belanja mereka, 1 responden mengalami kerugian karena kebijakan kantong plastik berbayar serta 1 responden ternyata mendapatkan keuntungan dengan adanya kebijakan plastic berbayar.

Hampir seluruh responden yang berasal dari toko modern berjaringan di Kota Denpasar maupun Kabupaten Badung menyatakan bahwa penentuan menerapkan kebijakan plastik berbayar atau tidak, berasal dari kebijakan kantor pusat jaringan mereka masing-masing. Sehingga sesuai dengan keputusan Asosiasi Pengusaha Retail Indonesia (APRINDO) yang menyatakan mencabut aturan plastik berbayar untuk sementara per November 2016.

Sedangkan toko modern yang tidak ikut dalam jaringan, memiliki wewenang untuk menentukan menerapkan kebijakan plastik berbayar. Sebagian besar dari responden menyatakan keputusan mereka dipengaruhi oleh pemikiran 
untuk mempertahankan konsumen. Sehingga mereka tidak menerapkan kebijakan plastik berbayar, untuk menghindari keluhan dari konsumen.

\section{SIMPULAN DAN SARAN}

\section{Simpulan}

Berdasarkan hasil analisis dan pembahasan yang dikemukakan sebelumnya, maka dapat diambil simpulan sebagai berikut ; Dari 53 responden toko modern di wilayah Kota Denpasar dan Kabupaten Badung, hanya 4 responden $(7,55 \%)$ yang menerapkan kebijakan plastik berbayar pada toko mereka, sedangkan 49 responden $(92,45 \%)$ tidak menerapkan kebijakan kantong plastik berbayar. Sebagian besar toko ritel modern menyatakan jumlah konsumen yang berbelanja di toko mereka tidak mengalami perubahan setelah diterapkan kebijakan plastik berbayar pada periode April-Oktober 2016. Walaupun ada kebijakan plastik berbayar konsumen pada toko ritel modern tetap jumlahnya sehingga tidak menimbulkan dampak yang signifikan terhadap jalannya usaha toko ritel modern.

Dampak yang tidak signifikan tersebut pada akhirnya menyebabkan kebijakan plastik berbayar yang coba diterapkan oleh pemerintah berjalan tidak efektif dan tidak berlanjut sebagaimana yang diharapkan. Kendala yang dihadapi antara lain ; kebiasaan masyarakat dalam menggunakan kantong plastik dalam kehidupan sehari-hari, belum adanya aspek peduli lingkungan dalam sikap masyarakat menggunakan kantong belanja sehingga lebih memilih kantong plastik yang praktis dan ekonomis. 
Saran

Saran yang dapat diberikan pada penyusun kebijakan publik antara lain ; a) Dapat mencoba implementasi tarif berbayar yang lebih tinggi dibandingkan sebelumnya yang hanya Rp.200,- untuk tiap kantong plastik, harga yang lebih tinggi akan mendorong konsumen untuk membawa kantong belanja sendiri daripada menggunakan kantong plastik, b) Mencoba bekerjasama dengan LSM dan Organisasi Pemuda untuk menyebarkan informasi dampak lingkungan jika menggunakan kantong plastik secara berlebihan, selain itu dapat dilakukan kegiatan-kegiatan yang fokus pada kepedulian lingkungan dan daur ulang sampah plastik.

\section{REFERENSI}

Andrady A. L. \& Neal M. A. 2009. Applications and societal benefits of plastics. Philosophical h'Transactions of the Royal Society . Vol. 364 ,pp : 19771984

Becker, C. M., Ayscue, E., Brockett, S. J., Scarola, G., Kelley, T. 2014. Initiating Sustainable Behavior: Feel Good for Doing Good. Electronic Green Journal, Vol 1. No.37

Dunn, William N. 2003. Pengantar Analisis Kebijakan Publik. Edisi Kedua. Yogyakarta; Gadjah Mada University Press.

Dye, Thomas.R. 1987. Understanding Public Policy. Engelewood Chief, New Jersey Prentince - Hall Inc.

Earth Policy Institute. 2013. Earth Policy Institute - Data for Plan B Update 123, The Downfall of the Plastic Bag: A Global Picture, http://www.earthpolicy.org/plan_b_updates/2013/update123

Efriandi,T. 2010. Evaluasi Kebijakan Bantuan Langsung Tunai di Kabupaten Muara Enim (Studi Kasus di Kecamatan Lawang Kidul). Tesis. Program Studi Ilmu Administrasi. FISIP UI. 
Gusmayanti, I., Ramadhani, S.A., Igbal,M. 2011. Pengenaan Harga Kantong Plastik Sebagai Upaya Mereduksi Penggunaan Kantong Plastik di Depok , Jawa Barat. Program Kreativitas Mahasiswa. Universitas Indonesia. Depok.

He, Haoran. 2010. The Effects of an Environmental Policy on Consumers : Lesson from the Chinese Plastic Bag Regulation. Working Paper in Economics. No.453. University of Gothenburg. Sweden. June 2,2010. ISSN 1403-2473 (print). ISSN 1403-2465 (online)

Jambeck, J.R., Geyer, R., Wilcox, C., Siegler, T. R., Perryman, M., Andrady, A., Narayan, R., Lavender Law, K.. 2015. Plastic waste inputs from land into the ocean. Science Vol.347,pp : 768-771.

Kuncoro, Mudrajad. 2007. Metode Kuantitatif Teori dan Aplikasi Untuk Ekonomi dan Bisnis. Yogyakarta: UPP AMP YKPN.

Kotler, P. 1995. Manajemen Pemasaran: Analisis, Perencanaan, Implementasi dan Pengendalian. Jakarta: Penerbit Salemba Empat.

Martín, Javier L.M. 2015. Social Perceptions of Single-Use Plastic Consumption of The Balinese Population. Bachelor's Thesis in Natural Resources, Degree Programme in Sustainable Coastal Management. Novia University of Applied Science, Raseborg.

Meidiana, C. \& Gamse, T. 2010. Development of Waste Management Practices in Indonesia. European Journal of Scientific Research.. ISSN 1450-216X Vol.40 No.2.pp: 199-210.

Nugroho,R. 2009. Public Policy. Jakarta : Elex Media Komputindo.

Reardon, T., and Hopkins, R. 2006. The Supermarket Revolution in Developing. European Journal of Development Research. Vol.18.pp : 522-545.

Safitri, A.R. 2010. Dampak Retail Modern Terhadap Kesejahteraan Pedagang Pasar Tradisional Ciputat, Tangerang Selatan. Skripsi. Universitas Islam Negeri Syarif Hidayatullah. Jakarta.

Samuelson dan Nordhaus, 2001, Microeconomics, Boston Mcgraw - Hill.

Saraswaty, A.N. 2017. Why They Still Want To Use It? : Plastic Bag Policy Application on Modern Retailers and Consumers. Proceeding. The $6^{\text {th }}$ IRSA International Conference, 17-18 July 2017 Manado.

Thoha, M. 1992. Dimensi-dimensi Prima Ilmu Administrasi Negara. Jakarta: PT. Grafindo Persada. 
Thomas, R. L. 1997. Modern Econometrics an introduction. Addison Wesley Longman, England.

Widodo, J. 2008. Analisis Kebijakan Publik. Jakarta. Bayumedia.

Wahab, S.A. 1997. Analisis Kebijakan Dari Formulasi Ke Implementasi Kebijaksanaan Negara. Jakarta : Bumi Aksara.

YLKI. 2016. Hasil Survei : Efektivitas Uji Coba Kebijakan Kantong Plastik Berbayar Pada Ritel Modern, April 2016, http://ylki.or.id/2016/04/hasilsurvei-efektivitas-uji-coba-kebijakan-kantong-plastik-berbayar-pada-ritel$\underline{\text { modern/ }}$ 